\title{
Leadership Attitude and Clan-Structure: Lessons for Leadership Practices in Contemporary Post-Conflict Nation Building in Somalia
}

\author{
Abdisamad Hassan \\ College of Law Government and International Studies, Universiti Utara Malaysia, Sintok, \\ Kedah 06010, Malaysia
}

\begin{abstract}
The study analyses the implication of the relationship between leader attitude and Somali Clan-Structure in post-conflict nation-building. The research questions were drawn from a review of relevant literature. Ten subjects were interviewed as a sample to achieve the study objective. Data were thematically analysed using a combination of social identity and reification theories. The results show that clan structure significantly influences Somali leadership attitude in nation-building. The paper argues that since it is clear that the reified clan system exerts a strong unfavourable influence on the future attitudes of Somali leaders towards nation building, the clan structure must be repositioned. Notably, the study discovered that the rise and fall of Siad Barre's efforts in nation-building relate to the adverse influence of Clan-Structure on the leader's attitude. As glaringly made clear by this study, attitudes that adversely affected nation-building in Somalia, as depicted by Siad Barre, were dictatorial, nepotistic, egoistic and survivalist. The consequence has been the fragmentation of the Somali political system into clan particularism resulting in a survivalist race and determination of leadership attitude. The study concludes that despite the centrality of Clan-Structure in shaping Somali leaders' attitudes, there is the necessity for a radical departure towards more constitutional-democratic practice for success in postconflict nation-building. The study presented some recommendations on reforms in relation to clan structure and leadership attitude towards a more constitutionally relevant PCR.
\end{abstract}

ARTICLE INFO

Article history:

Received: 17 January 2021

Accepted: 28 July 2021

Published: 24 September 2021

DOI: https://doi.org/10.47836/pjssh.29.3.22

E-mail address:

cabdisamad0001@gmail.com
Keywords: Clan structure, leadership attitude, nationbuilding, post-conflict reconstruction, Somalia

\section{INTRODUCTION}

After more than a decade of civil war, Somalia, like several societies ravaged by conflicts, is now transitioning into 
post-conflict stages of nation-building (Farah \& Handa, 2015). While studies have established that nation-building in a post-war society is a mammoth task, one of the key challenges in the case of Somalia appears to be the retrogressively historical influence of clan structure instituted by Siad Barre's regime (Ingiriis, 2016a, 2016b, 2016c). Although the clan phenomenon has existed in Somalia for centuries, it has, become a topical issue of discourse in relation to being the most critical factor to reckon with as far as the ideological basis for the acquisition of power and legitimacy in Somali politics is concerned. The central argument of this research is that the leadership attitude of President Barre remains an important pointer to the need for a departure from the heavy traditional patronage of the clan structure as a major determinant of leadership attitude in nationbuilding towards a more constitutional democratic leadership attitude. Finally, the paper offered suggestions for a constitutional alternative post-conflict leadership attitude model adaptation for Somalia.

\section{Conceptual Departure and Theoretical Orientation}

Ancient Egyptians was once described Somalia as "the land of Punt, a fabled source of wealth and luxury" (Adibe, 1995, as cited in A. A. Ismail, 2010, p. 9). However, today's description of it is far from that of luxury. It is well documented that clan structure forms the basis for local politics among Somalis (Hassan et al., 2019; I. Ismail, 2010). However, the transformation and emergence of clan structure as the sole determinant of what, when and how Somali leadership attitude exists became well pronounced during the colonial era and culminated with the regime of Siad Barre. After only nine years of democracy in 1969, President Abdirashid Ali Shermarke was assassinated when the military staged the 1969 coup d'état on October 21 and Siad Barre, a major general gendarmerie, became President of Somalia. Immediately after ascending power, Siad Barre destroyed democratic institutions and imposed a dictatorship that divided the society along with clan affiliations. Barre rewarded his supporters during his military rule, and jailed and even executed his opponents (Ingiriis, 2016c). Shortly after seizing power and the subsequent implementation of "scientific socialism" through the eradication and complete transformation of the clan structure in line with socialism, the so-called unification and eradication of ancient clan divisions led to the clan system being officially banned and made a serious crime punishable by law. Barre employed revolutionary rhetoric in which he presented himself as the "Father" of the Somali nation whose "Mother" was his revolution (Ingiriis, 2016a, 2016d).

Further, intensive media propaganda and orientation at various levels were instituted to consolidate power and control over Somalia. To this effect, Barre introduced Socialist Ideologies to serve as the basis for public orientation towards accepting socialism as the ideal society Somalis should appreciate (Muhammad 
et al., 2017). On the symbolic level, Barre replaced the concept of "Whom do you know" to "What do you know". He also introduced greetings, such as the singular jaalle (comrade) or the plural jaalleyaal (comrades; Cali \& Cawad, 2001). The main objective of the new form of greeting was to re-orient the public away from clan loyalty towards modern socialist nationalism, while comradeship was to ensure a singular line of thought among Somalis. Other aspects of the socialist ideology and control included, among others, setting up several cooperative farms and factories of mass production and new collective settlements of small villages known as the Danwadaagaha. As part of Barre's socialist policies, major industries and farms were nationalised, including banks, insurance companies and oil distribution farms.

An important landmark in transforming of the clan structure into a political one was the Clan Klatura policy, which refers to substituting of government officials with loyal clansmen, specifically from three clans, code-named MOD (Iazzolino, 2020; Ingiriis, 2016b). Barre adopted Clan-Klatura as a policy based on "clannism" after the Ogaden War to serve as the new ideology. It became apparent that socialism could not serve to perpetuate him in power. For the Clan-Klatura policy implementation, a 120,000 strong army was built for internal repression and control to ensure the dominance of the MOD. When the ClanKlatura policy was put in action by Barre, the Isaaq Clan was singled out for a "neofascist" type of punishment (Adam, 1994), resulting in internal resistance movements, such as the Somali National Movement (SNM) established by the Isaaq Clan and the Democratic Front for the Salvation of Somalia (DFSS) by the Majeerteen-Darod clans in 1978 (Adam \& Ford, 1997).

Despite Barre's obsession with Soviet guidance, it turned out that not everyone in Somalia condoned the socialist path taken by his regime (Muhammad et al., 2017). Ironically, while Barre overtly sought measures to eliminate clan and lineage divisions, the only option open to him was to overtly rely on older, time-honoured ties of loyalty that became handy at that moment. Further, the value of clan loyalties became more prominent when Barre's regime survived an unsuccessful coup by the Majeerteen Clan in 1978 (Ingiriis, 2016c, 2016d). Thus, the need to resort to clan structure as a necessity culminated to the peak.

\section{Leadership and Attitude}

The appropriateness of leadership in society correlates with nation-building. It manifests in how a leader's attitude influences on the levels of economic success, higher growth (Fukuyama, 2008; Putnam, 2016; Russell, 2017; Siisiainen, 2003) and civic engagement (Putnam, 2001). Thus, literature abounds to indicate how the attitudes of any leadership can facilitate nation-building through holistic social and economic approaches (Cortez \& Johnston, 2020; Croson, 1999; Sheer, 2015; Walker \& Kavedžija, 2015), yet little is emphasised on why nation-building is hard to be 
attained when there is an attitudinal flaw in leadership. Therefore, as the writer argued, a good quality leadership attitude is critical via attitudinal and behavioural components that can promote good governance, reduce social disintegration, increase social participation, enhance social welfare and ultimately culminate into successful nationbuilding. The fact that different countries have different historical antecedents, which determine the quality of leadership, suggests that institutions play an important role in shaping the attitudinal components of leadership. While the existing literature discusses the determinants of leadership quality from different perspectives (Hassan et al., 2019), the possible impact of clan institutions on the general evolution of leadership attitudinal components on nationbuilding is not well researched (Winston \& Fields, 2015). Some observations in Somalia's current situation may suggest that the leadership crisis confronting the country at the national level is rooted in the historical influence of clan institutions on the attitudinal components of leadership in national development. As noted by Lewis (2002), "If all Somalis are to go to hell, tribalism will be their vehicle to get there" (p. 22).

An attitude is the learned and global evaluation of a person, object, place or issue that influence thought and action (North \& Fiske, 2015; Omer et al., 2015). While an attitude as a construct hypothetically represents an individual's extent of like or dislike for something, attitudes are generally positive or negative views. Within the
Jungian perception of attitude, the emphasis is on a readiness of the psyche to act or react in a certain way towards an attitude object (Sermabeikian, 1994). An attitude as a social value refers to a general pattern in a group, resulting from communication and acting as an important determinant of the behaviour of a person as a group member (Lloyd-Sherlock, 2018). Thus, attitudes provide a mechanism of social control and a tendency towards influencing individual and group activity. In Somalia's history of nation-building, a variety of attitudes played critical roles. It seemed to have played an important role in the current state of affairs with regard to nation-building, ranging from a warlordism attitude, parochial attitudes, nationalist attitude and a strong seminary attitude (Abdi, 2011; Bryden, 2003; Ingiriis, 2016b; Omar \& Omar, 2015).

The theoretical orientation of the paper is the social identity theory developed by Tajfel (1979; as cited in Insko et al., 1992; Tajfel \& Robinson, 2002). Recent theoretical and methodological discussions (Mathende \& Nhapi, 2018; Rabiee, 2017; Wallen \& Fraenkel, 2013) have provided new inspirations to apply this theory for empirical studies in leadership attitude (Hassan et al., 2019; Wu \& Parker, 2017). Thus, the social identity theory was used to conceptualize the relationship between Clan-structure and Barre's leadership attitude in nation-building. Further, the transformation of clan structure from its original formation into a political machine in the era of Barre's regime was analysed using Reification (Arato, 1972; Barton \& Hamilton, 2005; Gartman, 1991). 


\section{Literature Review}

Ancient Egyptians Somalia was once described as "the land of Punt, a fabled source of wealth and luxury" (Gerhart \& Ginifer, 1996, as cited in A. A. Ismail, 2010, p. 9). Butut today's description is far from any description of luxury due to the long-standing and equally devastating conflict rooted in the relationship between clan structure and leadership attitude. Within the current decade, several studies have noted that Somalia, like several societies ravaged by conflicts, is now moving towards various phases of Postconflict nation-building (Gure et al., 2016; Omer et al., 2015). Related studies on Post-conflict nation-building have proposed various issues to be addressed in Somalia, including constitutional transformation and the restoration of the collapsed central government (Berardi, 2002; Farah \& Handa, 2015; Giustozzi, 2016; Mutahi \& Ruteere, 2017). However, a major challenge neglected by these studies, which must be faced by any current or potential Somali leadership, appears to be the menace of clan structure on the attitude of leadership.

The clan's influence on leadership attitude can be inferred from several other studies on the role of previous leadership, who maintained power by the manipulation of clan lineage (I. Ismail, 2010; Makhubela \& Schoeman, 2010). It is evident in postindependence Somalia that except for President Adam Abdulle, most leaders in Somalia directly contributed to the disintegration of the society by depicting attitudes of favouritism and oppressing their opponents (Cotran \& Rubin, 2021). Moreover, whenever Somalia leaders felt that their clan's support was waning, they formented clan tensions that crowned them to protect their clan and unite it to support them. Further, Somali leaders have also corrupted the political system and prevented establishing solid and inclusive political and economic institutions. For example, President Barre offered all the important positions in the government to his MOD alliance to support the perpetuation of his leadership.

Further, Barre mostly excluded the public from important state military and civilian posts (Ingiriis, 2016b). Thus, again, the compartmentalisation of the Somali society into hostile divisions is attributed to his leadership flaws and attitude. As a result, it created the political divide and rule that has deterred any success in attempts towards nation-building. Nevertheless, recent studies have paid less attention to the disintegration of Somali society as a function of leadership attitude. Therefore, leadership attitude and what attitude change can play in achieving the PCR success in nation-building imply a gap in the current literature.

\section{MATERIALS AND METHODS}

The research justification for the chosen methodology stems from the nature of reality or ontology. In this research, ontology is blended by historical and political contexts resulting in the socially constructed reality that can be understood through constructivism and qualitative observational research paradigms (Guarino 
\& Guizzardi, 2016; Scotland, 2012). It is based on the perception that the nature of reality in contemporary political issues in Somalia is largely a matter of historical forces and realism shaped by both values and contexts. That is to say, social issues arise from historical reality and are, therefore, maintained by both past and present circumstances. As such, understanding and making meaning out of current reality requires an inquiry through a qualitative approach. Consequently, the methodology of this paper follows from both ontology and epistemology (Feast \& Melles, 2010; Hassan \& Shahid, 2010). Thus, this study shall use a qualitative research methodology to explore the relation between clan structure and leadership attitude in nation-building. This qualitative research will draw from several disciplines, such as sociology, social psychology and political science (Merriam, 2002) and others that describe the meaning of clan structure and its relation to leader attitude in nationbuilding socially constructed.

\section{Data Collection Instrument}

The paper used qualitative methods based on two types of data, namely primary data generated through in-depth interviews with experienced and knowledgeable individuals about the subjects under study (Yakubu \& Namadi, 2018). The aim was to explore the relationship between Clan-Structure and leadership attitude in Somali nationbuilding. The role of the researcher is to interview and analyze the data from selected members.

\section{Techniques of Data Collection}

The data collection techniques were interviews for which notes were taken and recorded based on the interviewees' responses. Therefore, the study utilised faceto-face interview to ensure that questions in the interviews guides were meaningful and easily understood by the informants (Rahman \& Yakubu, 2017).

\section{Population of the Study}

The informants in the study comprise public figures. Ten (10) were interviewed for this study to explore the information needed to achieve the research objective. Interview settings were convenient to the members participating. A high sense of confidentiality was observed. The interviews were guided by semi-structured questions to explore the needed responses.

\section{RESULTS}

The goal was to analyse the relationship between Somali Clan-Structure and leader attitude in post-conflict nation-building. The term "informants" is used here as the subjects in this study, who informed us of their perceptions and suggestions. Central to the discussion was the implication of the relationship between Somali ClanStructure and leader attitude, as a source of the lesson to be adapted for post-conflict nation-building. The data that emerged were analysed through a thematic approach, which effectively and appropriately offers a trail of evidence on how the data revealed relevant issues that explicitly accomplished the objectives set by the study. 


\section{Demographical Profile}

Table 1 shows all the informants who participated in the study $(\mathrm{N}=10)$. Most of the informants $(\mathrm{N}=9)$ were professionals working in public and private sectors from the table. Only one informant was not a professional but still had a critical role as a clan leader. Based on the demographic profile of our informants, it was clear that $90 \%$ were elites in a good position to discuss issues of relevance to nationbuilding in Somalia. The informants also served in various capacities in both politics, finance, diplomacy and education. However, only Informant 8, on the other hand, was not highly educated but represents the perspective of traditional clans in Somalia regarding nation-building.

\section{The Role of Social Identity and Attitude Formation in The Rise and Fall of Siad Barre}

The emergence and fall of Siad Barre as a prominent Somali dictator provide significant evidence of how Clan-Structure shapes personal identity and leadership attitude in nation-building. Going by Tajfel (1982) proposition, clans are important sources of pride and self-esteem that gave Siad Barre a sense of social identity and belonging upon which his leadership attitude rested. Thus, the present study noted the use of brute force to remain in power as a depiction of an aggressive predatory attitude. Therefore, it was not unexpected that internal resistance movements emerged along clan identity lines, for example, the Democratic Front for the Salvation of Somalia (DFSS) formed in 1978 by Majeerteen-Darod and the Somali National Movement (SNM) established by the Isaaq Clan. In addition, the Clan Klatura policy shows that from the emergence of Siad Barre to his fall, the background was set and ripe to display a variety of attitudes evident in the next section.

\section{Attitude Depiction and Pitfall in Nation Building in the Style of Siad Barre}

Siad Barre depicted various attitudes. Initially, his military rule adopted an attitude that deliberately disregarded the clan

Table 1

Demographic profile of informants

\begin{tabular}{lllll}
\hline Informant & Country & Age range & Career Background & Level of Education \\
\hline Informant 1 & Somalia & 54 years & Diplomat & MSc \\
Informant 2 & Somalia & 37 years & Public Servant & $\mathrm{PhD}$ \\
Informant 3 & Somalia & 45 years & Public Servant & $\mathrm{Msc}$ \\
Informant 4 & Somalia & 44 years & Politician & $\mathrm{Msc}$ \\
Informant 5 & Somalia & 54 years & Academician & $\mathrm{PhD}$ \\
Informant 6 & Somalia & 35 years & Activist & $\mathrm{PhD}$ \\
Informant 7 & Somalia & 34 years & Public servant & Msc \\
Informant 8 & Somalia & 64 years & Clan leader & Primary School \\
Informant 9 & Somalia & 57 years & Cleric & Bachelor's Degree \\
Informant 10 & Somalia & $25-34$ years & Woman Activist & Bachelor's Degree \\
\hline
\end{tabular}


component as the official attitude to nationbuilding in his regime (Farah \& Handa, 2015; Tajfel et al., 1971). However, the consequence of disregarding the clan structure resulted in the federal state system he instituted failing, implying that such disregard was functional to the catastrophe in his attitude to nation-building. For example, shortly after seizing power, he depicted a major dictatorial attitude adopted from scientific socialism, which aimed to actualise the unification of the nation and eradicating its ancient clan structure. The socialist attitude to nation-building led to the clan system being officially banned and defined as a serious criminal offence. Further, eradicating all the rudiments of clan ideology was achieved by employing an aggressive predatory attitude that seemed revolutionary. As noted by Informant 6 ,

It was rhetoric in which Siad Barre presented himself as the "Father" of a modern Somali nation whose "Mother" was his revolution. There was intense radio propaganda at local orientation centres to inculcate this new ideology into the mindset of Somalis While Barre overtly sought measures to eliminate clan and lineage divisions and sow the seeds of national solidarity. Unfortunately, he was also "underhandedly relying on the older, time-honoured bonds of loyalty.

When Barre realised that scientific socialism was not enough to consolidate his rule after his regime survived an unsuccessful coup in 1978, he depicted a major slanderous attitude in nationbuilding. Thus, in place of a constructional democratic strategy in nation-building, Siad Barre's attitude resorted to heighten the general attitude of Somalis towards clan loyalty. With the heavy reliance on clan structure by Barre, resistance and the consequent formation of armed opposition ensued. In addition, as noted by Informant 3, "A series of events led to widespread public demoralisation and upsurge of clan loyalties, as different groups sought scapegoats to explain the debacle."

Barre witnessed more armed groups vying to dislodge him from power, so he transitioned into a survivalist attitude. $\mathrm{He}$ consolidated nepotism by acknowledging the preeminent standing of the clan institution in Somalia-an attitude that became a compelling reality calling for the clan loyalties he once sought to abolish. Thus, Barre dropped the "scientific socialism" attitude as his guiding ideology by reverting to the oppressive clan structure at the cost of pure constitutional democracy.

Barre consolidated clan power more and more within the Marehan. By 1987, it was projected that more senior officer corps belonged to the President or related clans. The proportion was higher in the artillery and tank brigades within the new southern command unit headed by Siad's son, General Maslah. (Informant 6)

Concerning the above position, clan dogma, which obligates patrilineal kinsmen to stand with one another, enabled Barre 
to reconfigure the military for reliance on clan structure. Furthermore, contrary to expectation, Barre depicted a different set of attitudes by not resorting to Islam. It was evident in the implementation of ClanKlatura.

In the Clan-Klatura policy, efforts were geared at implementing clan-based governance based on loyalty by substituting government officials with loyal clansmen. The substitution was specifically made from three clans, code-named MOD. (Informant 8)

Thus, a major component of the attitude that served as the basis of the regime's philosophy of nation-building was nepotism. As further explained by Informant 2, "in the code MOD, M represents Barre's patrilineal clan the Marehan; the $\mathrm{O}$ for Ogaden, his mother's clan; and D for Dhulbahante, his son in law's clan who was also head of the National Security Service."

Barre's need to ally with these three particular clans reflects the ability of the clan system to foster attitudinal elements in nation-building. However, conversely, and the deleterious effect on national cooperation at the clan level that nationbuilding could have fostered. Thus, rather than the conventional democratic governance model applied widely for nation-building, this intricate grouping of clan families only enabled Barre to achieve his egoistic satisfaction by generating the necessary level of cooperation otherwise conventionally not attainable through the socialist attitude. Significantly, clan loyalty shaped Barre's regime attitude towards eventual failure.

Another attitude depicted in nationbuilding in Barre's regime was divide and rule or the fragmentation of the political system into 62 parties to accommodate clan particularism. Informant 5 noted that "Clan-structure was utilised to differentiate between candidates because choosing a candidate outside of the clan would result in losing access to state funds."

It was implored to instigate a race between clans and mobilise them towards serving as a means to an end, namely seize the spoils of elections in the form of public resources. Thus, access to national resources was made paramount at the expense of national integration. The clan institution remained a gateway to accessing communally controlled resources, which were seen as the most effective mechanism for securing political dominance.

\section{DISCUSSION}

Generally, the leadership attitude in the history of Somali nation-building is determined to a greater extent by a personal identity derived from the clan system. Since all political power tends to emanate from the clans as the highest point of political division, the supremacy associated with clan interests forced all potential and incumbent Somali leaders into absolute compliance to cement their respective clans' loyalty. An important personality in the Somali political landscape has been Siad Barre. He was shaped by the clan structure, as 
depicted in his leadership style and attitude throughout his emergence and fall. Further, clan affinity defined how Siad Barre related fellow Somalis from other clans in the socio-political process. In this sense, his attitude towards citizenship was not based on democratically determined constitutional duties and responsibilities of being a citizen of Somalia but based on affiliation to a clanfamily. Thus, the central theme upon which the attitudinal components of Siad Barre's leadership in Somali politics revolved tends to be around the clan structure. The implication of this on the Somali experience of Siad Barre's nation-building has been a failed attempt.

It is clear that the clan system exercised a strong influence on the legitimacy of Siad Barre's government. In this regard, the criteria for Siad Barre's attitudinal components publicly manifested in executing national development as determined by the influence of Clan-Structure. Thus, Siad Barre's political philosophy derived on the basis for legitimate power via a leadership attitude that reflected the degree of acceptability in the representation of every clan member in his government (Brinkerhoff, 2005). In addition, Siad Barre pretended that clans were in command and had a say in the political and economic issues related to the part of the country they inhabited in his government.

Thus, Siad Barre's ideological mission was to prove that Somalis were not historically familiar with effective democratic leadership styles, but they are very comfortable with leadership that accommodated all clan and sub-clan aspirations (Fuad et al., 2016; Ingiriis, 2016b). This finding is substantiated by the historic failure of previous leaders in Somalia that have otherwise approached Clan-Structure. Its institutionalisation as the basis for leadership legitimacy has cost Somalia colossal losses in its quest for nation-building. Therefore, a new philosophy must emerge to catalyse the departure of the political process in Somalia from clan dominance to a constitutional democratic process.

\section{CONCLUSION}

Conclusively, the perceived centrality of clan structure to Somali culture suggests its culpability in shaping the personalities and hence, the attitude of Somali leaders and their subsequent failure or success. Further, the enduring nature of the clan system in Somali politics suggests the attribution of a great deal of value to its organisational ability. Therefore, it is evident that Somalis would want to see it reflected within the overall attitude of their leaders and their leadership styles. From this study, it is clear that the Somali state's 'failure' and 'collapse' rests on how leadership attitude rests on clan structure.

\section{Future Directions}

The present research was conducted among the "elite" in Somalia. Therefore, it would be interesting to know the results that would evolve from the other segments of Somali society like the masses and uneducated persons in rural and remote areas. Future 
studies should also focus on the women since, in all likelihood, the results to emerge from such studies will either provide additional information to this study or serve as comparative views on the subject. In the final analysis, future studies should extend the research frontier to include other factors. The different perspectives gathered from such research will guide the new leadership to adopt better strategies for social reintegration.

\section{Recommendations}

The study offered the following recommendations:

The informants made various suggestions on the way forward in Somalia's quest for answers in nation-building. While some informants suggested participatory leadership, others suggested the Islamic style of leadership that leans to the past. More informants also recommended overcoming socio-economic disparities and social exclusion in addition to neutrality in international relations. As suggested by some informants, the participatory leadership approach is a potential option if adapted to suit local values, culture and religion by ensuring that all stakeholders are carried along.

Further, the viability of a participatory leadership style tends to be highly dependent on adaptation as an Islamic situational model. Such a model based on Islamic tenets stands to be highly potent due to the solidarity it might enjoy among Somalis. This advantage can be viable for social reconstruction. Furthermore, the research also found that in adapting the Islamic participatory model of situational leadership, an inclusive framework should be developed to address the socio-economic disparities that perpetuate insecurity and instability to improve the current situation of social inclusion. To further sustain the model, there must be inclusive political, economic and social institutions as major initiatives for integration to ensure broader participation and adequate representation to all groups in the country. The research establishes that the leadership style appropriate for the Somali situation is directing and coaching that imply a model based on Islam and democracy.

Further recommendations by the author are as follows:

- The current PCR needs to mobilise structures towards broadening national solidarity and leadership personalities that accept the wider application of the nation-building principles against clan structure manipulation.

- In place of misappropriating the notion of Somali Homogeneity as a means of retaining power, the existing clan structures should serve as aspiration mobilisers towards nation-building and constitutional democracy.

- There is the need to ensure that the mechanisms of political representation are reviewed to prevent individuals with a dark history, such as warlords and Islamist extremists, from representing their 
clans in the political process.

- There is the need to broaden public participation through incentives that favourably encourage youth, educated individuals and women across clans to participate fully in the recovery and reconstruction process.

- While respecting clan structure, the leadership should avoid the continuation of clan domination in the political process and devise a more democratic system that is inclusive and sustainable in the long run.

- The desired democratic system should balance clan inclusion with competence by attracting people with integrity and education to represent clans in the political system to discourage spoilers from dominating the system and ensure fair and equitable resource allocation for all Somalis.

- More importantly, the new system should prohobit clan infiltration and influence in the administration, judiciary, law enforcement and military from preventing the state apparatus against some groups while ensuring that all Somalis benefit equally from state services regardless of their clan affiliation.

\section{ACKNOWLEDGEMENTS}

The researcher is grateful to the ten discussants, including officials from the Interior Minister, former officials from the Union of Islamic Courts, the Rector of Institutional Development at Simad University, the Vice-Chancellor of Mogadishu University, Civil Society Activists and the Somali Ambassador to Malaysia.

\section{REFERENCES}

Abdi, C. M. (2011). Moving beyond xenophobia: Structural violence, conflict and encounters with the "other" Africans. Development Southern Africa, 28(5), 691-704. https://doi.org/10.1080 /0376835X.2011.623916

Adam, H. M. (1994). Formation and recognition of new states: Somaliland in contrast to Eritrea. Review of African Political Economy, 21(59), 2138. https://doi.org/10.1080/03056249408704034

Adam, H. M., \& Ford, R. B. (1997). Mending rips in the sky: Options for Somali communities in the 21 st century. Sea Press.

Arato, A. (1972). Lukacs' theory of reification. Telos, 1972(11), 25-66. https://doi. org/10.3817/0372011025

Barton, D., \& Hamilton, M. (2005). Literacy, reification and the dynamics: Of social interaction. Beyond Communities of Practice: Language, Power and Social Context, 14-35. https://doi.org/10.1017/ CBO9780511610554.003

Berardi, G. (2002). Commentary on the challenge to change: Participatory research and professional realities. Society \& Natural Resources, 15(9), 847-852. https://doi. org/10.1080/08941920290107594

Brinkerhoff, D. W. (2005). Rebuilding governance in failed states and post-conflict societies: Core concepts and cross-cutting themes. Public Administration and Development, 25(1), 3-14. https://doi.org/10.1002/pad.352

Bryden, M. (2003). No quick fixes: Coming to terms with terrorism, Islam, and statelessness 
in Somalia. The Journal of Conflict Studies, XXIII(1), 47-75.

Cali, A., \& Cawad, I. (2001). Diiwaanka Maansadii Deelley (1979-1980). Ururin iyo faallo. Tenzone poetica in lingua somala [Collection of poems by Deelley (1979-1980): Collection and commentary: Tenzone poetica in lingua somala]. Harmattan Italia

Cortez, R. M., \& Johnston, W. J. (2020). The Coronavirus crisis in B2B settings: Crisis uniqueness and managerial implications based on social exchange theory. Industrial Marketing Management, 88, 125-135. https://doi. org/10.1016/j.indmarman.2020.05.004

Cotran, E., \& Rubin, N. N. (Eds.). (2021). Annual survey of African Law Cb: Volume One: 1967. Routledge.

Croson, R. N. B. (1999). Gender and culture: International experimental evidence from trust games. JSTOR, 89(2), 386391.

Farah, I., \& Handa, S. (2015). Exploring post-conflict reconstruction in Somalia: Pulling apart or pulling together? Development, 58(1), 112-116. https://doi.org/10.1057/dev.2015.27

Feast, L., \& Melles, G. (2010, June 28-July 1). Epistemological positions in design research: A brief review of the literature [Paper presentation]. International Conference on Design Education, University of New South Wales, Sydney, Australia.

Fuad, M., Ali, B. A., \& Sanchez-Sibony, O. (2016). The Somali clan system: A road map to political stability in Somalia [Unpublished master's thesis]. Texas State University. https://digital. library.txstate.edu/handle/10877/6122

Fukuyama, F. (2008). State-building in the Solomon Islands. Pacific Economic Bulletin, 23(3), 1-17.

Gartman, D. (1991). Culture as class symbolization or mass reification? A critique of Bourdieu's distinction. American Journal of Sociology, 97(2), 421-447. https://doi.org/10.1086/229784
Giustozzi, A. (Ed.). (2016). Post-conflict disarmament, demobilization and reintegration: Bringing statebuilding back in (1st ed.). Routledge. https://doi. org/10.4324/9781315601656

Guarino, N., \& Guizzardi, G. (2016). Relationships and events: Towards a general theory of reification and truthmaking. Lecture Notes in Computer Science (Including Subseries Lecture Notes in Artificial Intelligence and Lecture Notes in Bioinformatics), 10037 LNAI, Springer, Cham. https://doi.org/10.1007/978-3-319-49130-1_18

Gure, F., Dahir, M. K., Yusuf, M., \& Foster, A. M. (2016). Emergency contraception in post-conflict Somalia: An assessment of awareness and perceptions of need. Studies in Family Planning, 47(1), 69-81. https://doi.org/10.1111/j.17284465.2016.00047.x

Hassan, A., Mohd Zain, Z., \& Na'iem Ajis, M. (2019). Social integration in post conflict Somalia: implications for a situational leadership style framework. Asian Journal of Multidisciplinary Studies, 7(3), 41-50.

Hassan, A., \& Shahid, M. A. (2010). Management and development of the awqaf assets. In A. G. Ismail, M. E. Mat Hassan, N. Ismail \& S. Shahimi (Eds.), Proceedings of Seventh International Conference The Tawhidi Epistemology: Zakat And Waqf Economy (pp. 309-328). Institut Islam Hadhari.

Iazzolino, G. (2020). Power geometries of encampment. The reproduction of domination and marginality among Somalis refugees in Kakuma. Geoforum, 110, 25-34. https://doi. org/10.1016/j.geoforum.2020.01.010

Ingiriis, M. H. (2016a). How Somalia works: Mimicry and the making of Mohamed Siad Barre's Regime in Mogadishu. Africa Today, 63(1), 57. https:// doi.org/10.2979/AFRICATODAY.63.1.0057

Ingiriis, M. H. (2016b). Many Somalia(s), multiple memories: Remembrances as present politics, past politics as remembrances in war-torn Somali 
discourses. African Identities, 14(4), 348-369. https://doi.org/10.1080/14725843.2016.1143804

Ingiriis, M. H. (2016c). The suicidal state in Somalia: The rise and fall of the Siad Barre regime, 1969-1991. University Press of America.

Ingiriis, M. H. (2016d). "We swallowed the state as the state swallowed us": The genesis, genealogies, and geographies of genocides in Somalia. African Security, 9(3), 237-258. https://doi.org $/ 10.1080 / 19392206.2016 .1208475$

Insko, C. A., Schopler, J., Kennedy, J. F., Dahl, K. R., Graetz, K. A., \& Drigotas, S. M. (1992). Individual-group discontinuity from the differing perspectives of Campbell's realistic group conflict theory and Tajfel and Turner's social identity theory. Social Psychology Quarterly, 55(3), 272. https://doi.org/10.2307/2786796

Ismail, A. A. (2010). Somali state failure: Players, incentives and institutions. Svenska handelshögskolan.

Ismail, I. (2010). Governance: The scourge and hope of Somalia. Trafford Publishing.

Lewis, I. M. (2002). A modern history of the Somali: Nation and state in the Horn of Africa, Eastern African Studies. Ohio University Press.

Lloyd-Sherlock, P. (2018). Population ageing and health. Population Ageing and International Development, 91-116. https://doi.org/10.2307/j. ctt9qgsfc. 11

Makhubela, L. M., \& Schoeman, M. (2010). Conflict resolution in Somalia: Learning From failed mediation processes [Master's dissertation, University of Pretoria]. http://hdl.handle. net $/ 2263 / 28151$

Mathende, T. L., \& Nhapi, T. G. (2018). The nexus of globalisation and global south social policy crafting: Some Zimbabwean perspectives. The Journal of Pan African Studies (Online), 12(1), 499-515.
Merriam, S. B. (2002). Basic interpretive qualitative research. In S. B. Merriam (Ed.), Qualitative research in practice (pp. 37-39). Jossey-Bass.

Muhammad, H. S. A. N., Azman, M. D., \& Rogers, R. A. (2017). Before things fall apart: The role of the Soviet Union in Somalia's troubled past (1969-1978). Intellectual Discourse, 25(2), 409-427.

Mutahi, P., \& Ruteere, M. (2017). Where is the money? Donor funding for conflict and violence prevention in Eastern Africa (IDS Evidence Report 217). https://reliefweb.int/report/southsudan/where-money-donor-funding-conflictand-violence-prevention-eastern-africa

North, M. S., \& Fiske, S. T. (2015). Modern attitudes toward older adults in the aging world: A crosscultural meta-analysis. Psychological Bulletin, 141(5), 993-1021. https://doi.org/10.1037/ a0039469

Omar, M. A., \& Omar, M. A. (2015). Somali elder care: A guide for healthcare in the West. Sociology Psychiatry Epidemiology, 27(9), 113-125.

Omer, M., Klomsri, T., Tedre, M., Popova, I., Klingberg-Allvin, M., \& Osman, F. (2015). E-learning opens the door to the global community. Novice users experiences of e-learning in a Somali University. Journal of Online Learning and Teaching, 11(2).

Putnam, R. D. (2001). Social capital: Measurement and consequences. Isuma: Canadian Journal of Policy Research, 2(1), 41-51.

Putnam, R. D. (2016). Bowling alone: America's declining social capital. In L. Crothers \& C. Lockhart (Eds.), Culture and Politics: A Reader (pp. 223-234). Palgrave Macmillan. https://doi. org/10.1007/978-1-349-62397-6

Rabiee, F. (2017). Focus-group interview and data analysis. Proceedings of the Nutrition Society, 63(4), 655-660. https://doi.org/10.1079/ PNS2004399 
Rahman, A., \& Yakubu, A. (2017). Jeedo practice among elderly women in Bauchi: A social capital prospects study. International Journal of Social Science and Economic Research, 2(12), 5627-5647.

Russell, T. (2017). 'Where goats connect people': Cultural diffusion of livestock not food production amongst southern African huntergatherers during the Later Stone Age. Journal of Social Archaeology, 17(2), 115-137. https:// doi.org/10.1177/1469605317701596

Scotland, J. (2012). Exploring the philosophical underpinnings of research: Relating ontology and epistemology to the methodology and methods of the scientific, interpretive, and critical research paradigms. English Language Teaching, 5(9). https://doi.org/10.5539/elt.v5n9p9

Sermabeikian P. (1994). Our clients, ourselves: The spiritual perspective and social work practice. Social Work, 39(2), 178-183. https:// doi.org/10.1093/sw/39.2.178

Sheer, V. C. (2015). "Exchange lost" in leader-member exchange theory and research: A "Exchange lost" in leader-member exchange theory and research: A critique and a reconceptualization critique and a reconceptualization. Leadership, 11(2), 213229. https://doi.org/10.1177/1742715014530935

Siisiainen, M. (2003). Two concepts of social capital: Bourdieu vs. Putnam. International Journal of Contemporary Sociology, 40(2), 183-204.

Tajfel, H. (1982). Instrumentality, identity and social comparisons. In H. Tajfel (Ed.), Social
Identity and Intergroup Relations (pp. 483-507). Cambridge University Press.

Tajfel, H., Billig, M. G., Bundy, R. P., \& Flament, C. (1971). Social categorization and intergroup behaviour. European Journal of Social Psychology, 1(2), 149-178. https://doi. org/10.1002/EJSP.2420010202

Tajfel, H., \& Robinson, W. P. (2002). Social groups and identities: Developing the legacy of Henri Tajfel (W. P. Robinson, Ed.). ButterworthHeinemann

Walker, H., \& Kavedžija, I. (2015). Values of happiness. HAU: Journal of Ethnographic Theory Journal of Ethnographic Theory, 5(53), 1-23. https://doi.org/10.14318/hau5.3.002

Wallen, N. E., \& Fraenkel, J. R. (2013). Educational research: A guide to the process. Routledge.

Winston, B., \& Fields, D. (2015). Seeking and measuring the essential behaviors of servant leadership. Leadership and Organization Development Journal, 36(4), 413-434. https:// doi.org/10.1108/LODJ-10-2013-0135

Wu, C. H., \& Parker, S. K. (2017). The role of leader support in facilitating proactive work behavior: A perspective from attachment theory. Journal of Management, 43(4), 1025-1049. https://doi. org/10.1177/0149206314544745

Yakubu, A., \& Namadi, M. M. (2018). The spiritual and religious practice of " jeedo" among elderly women in Bauchi Emirate of north eastern Nigeria. Journal of Techno-Social, 1, 1-14. https://doi.org/10.30880/jts.2018.10.01.001 
